\title{
Characteristics of landslides in unwelded pyroclastic flow deposits, southern Kyushu, Japan
}

\author{
M. Yamao ${ }^{\text {a, }}$, R. C. Sidle ${ }^{1}$, T. Gomi ${ }^{2}$, and F. Imaizumi ${ }^{3}$ \\ ${ }^{1}$ Sustainability Research Centre, University of the Sunshine Coast, Locked Bag 4, Maroochydore DC, Queensland \\ 4558, Australia \\ ${ }^{2}$ Department of International Environmental and Agriculture Science, Tokyo University of Agriculture and Technology, \\ Saiwai 3-5-8, Fuchu, Tokyo, 1585809, Japan \\ ${ }^{3}$ Faculty of Agriculture, Shizuoka University, 836, Ohya, Suruga-ku, Shizuoka, 4228529, Japan \\ a formerly at: Disaster Prevention Research Institute, Kyoto University, Gokasho, Uji, Kyoto, 6110011, Japan \\ $\dagger$ deceased
}

Correspondence to: R. C. Sidle (Rsidle@usc.edu.au)

Received: 5 September 2015 - Published in Nat. Hazards Earth Syst. Sci. Discuss.: 27 October 2015

Revised: 22 January 2016 - Accepted: 29 January 2016 - Published: 3 March 2016

\begin{abstract}
We investigated 184 landslides that occurred in unwelded pyroclastic flow deposits (Shirasu) on southern Kyushu Island, Japan, that included detailed data on the rainfall characteristics and the timing of slope failure. Localized rainfall intensity, antecedent precipitation index (API), and topography affected the hydrologic processes that triggered landslides. API (adjusted for evapotranspiration losses) for large $(>200 \mathrm{~mm})$ storms that triggered landslides was much lower than for smaller $(\leq 200 \mathrm{~mm})$ storms. Mean storm intensity and 7-day API $\left(\mathrm{API}_{7}\right)$ thresholds of $>5 \mathrm{~mm} \mathrm{~h}^{-1}$ and $\leq 30 \mathrm{~mm}$ (or $\mathrm{API}_{30} \leq 60 \mathrm{~mm}$ ), respectively, were useful to identify landslides triggered by rapid pore water pressure response, especially for shorter $(<20 \mathrm{~h})$ duration events. During smaller storms with lower intensity, landslides are likely affected by a combined increase in soil weight and loss of suction when $\mathrm{API}_{30} \geq 150 \mathrm{~mm}$; simulations indicated that these weight and suction changes due to rainfall accumulation decreased the factor of safety in steep Shirasu slopes, but did not necessarily trigger the landslides. Most of the landslides that were plotted below a general rainfall intensity-duration threshold for landslide initiation occurred during smaller storms with $\mathrm{API}_{30}$ values $>200 \mathrm{~mm}$, indicating that they were highly influenced by the combined effects of the accumulated weight of rainfall and loss of suction. Our findings show that both event rainfall characteristics and API affect the hydrogeomorphic processes that trigger different types of landslides in Shirasu. This knowledge and the
\end{abstract}

thresholds we have identified are useful for predicting the occurrence of different types of landslides in unwelded Shirasu deposits and improving sediment disaster prevention practices, including real-time warning systems.

\section{Introduction}

Volcanic deposits are highly susceptible to mass wasting and many related sediment disasters have been reported (e.g., Shimokawa et al., 1989; Crosta and Dal Negro, 2003; Ngecu et al., 2004; Bernard et al., 2009; Navarro et al., 2009; Cimarelli and de Rita, 2010; De Falco et al., 2012). Various types of landslides occur in these volcanic materials, including rock falls, flank collapses, rotational slumps, earthflows, debris slides, lahars, and debris flows, depending on the characteristics of the deposits and triggering mechanisms. For example, in the western Oregon Cascade Range, competent andesite and basalt lava flows overlie weathered volcaniclastic rocks that are highly altered due to water infiltration through cap rock fissures (Swanson and Swanston, 1977). These areas are susceptible to deep-seated mass movements and, where exposed in gorges, promote large rotational slumps (Palmer, 1977). Landslide frequency in the Hong Kong region was higher in areas underlain by dacitic and rhyolitic volcanic rocks compared to other lithologies (Dai and Lee, 2001). Because of the discontinuous nature of deposits on 
flanks of volcanoes, residual weak soil layers may act as slip surfaces of large landslides (Hürlimann et al., 2001). Such unique depositional patterns in volcanic residuals alter the hydrologic pathways and affect localized weathering of these materials. Interactions amongst hydrology, tectonics, and lithology can increase the occurrence of landslides in volcanic deposits (Sidle and Ochiai, 2006). Furthermore, high and intense rainfall on weathered volcanic materials (including ash) can trigger debris flows and devastating lahars (e.g., Suwa and Yamakoshi, 1999; Palacios et al., 2001; Lavigne and Thouret, 2003).

Shirasu is an unwelded pyroclastic flow deposit composed of dacitic tuff that covers large areas of southern Kyushu Island, Japan, particularly more than half of the prefecture of Kagoshima (e.g., Yokota, 1997; Hyodo et al., 2005). These Quaternary deposits have spread in a radius of more than $50 \mathrm{~km}$ by the eruptions of the Aira caldera about 25000 years ago (Miyagi, 1977; Aramaki, 1984; Nakaoka, 1988). Although these deposits are restricted to the southern $30 \%$ of Kyushu Island, this region of Japan experiences some of the most devastating landslide and debris flow disasters in the nation (e.g., Sidle et al., 2004; Teramoto et al., 2006; Taniguchi, 2008). Furthermore, because Shirasu is highly susceptible to landslides, this region provides a unique setting to investigate the magnitude and frequency of landslides, and the data presented herein should be useful in addressing these issues. Shirasu terrain is steep and often includes isolated butte and mesa landforms. These deposits are easily weathered and their strength and bulk density progressively decreases as weathering proceeds (Yokota, 1997). The areas covered by Shirasu in southern Kyushu are often affected by heavy rainfall during typhoons and Baiu frontal storms. Typhoons typically occur from August through October, while Baiu frontal systems occur in early June through late July. Most of these storms approach Kyushu Island from the south, delivering moist air from the sea, causing heavy rainfall once they strike land in Kagoshima. Thus, landslides in Shirasu deposits occur during most years and cause substantial property damage and causalities. For example, in early September 1993, typhoon Yancy delivered precipitation ranging from 180 to $543 \mathrm{~mm}$ in a $24 \mathrm{~h}$ period throughout south-central Kyushu, causing numerous landslides, resulting in extensive loss of life and property damage. In September 2005, typhoon Nabi struck southern Kyushu ( $>600 \mathrm{~mm}$ of rain in a 3-day period) triggering landslides, debris flows, and flash flooding, with a combined death toll of 27 (Teramoto et al., 2006; Taniguchi, 2008).

Various types of landslides occur in Shirasu deposits and cause different sediment-related disasters. For example, during the devastating typhoon Yancy in 1993 (229 mm of total rainfall in Kagoshima; maximum $1 \mathrm{~h}$ intensity $46.5 \mathrm{~mm} \mathrm{~h}^{-1}$ ), more than $90 \%$ of the landslides occurred on slopes $\geq 30^{\circ}$ (Fukuda, 2011). On very steep slopes, typically $\geq 50^{\circ}$, exfoliations with depths $<1 \mathrm{~m}$ repeatedly occur (Haruyama, 1974). During typhoon Nambi (4-6 September 2005), more than two-thirds of the landslides around the city of Tarumizu (southeastern Kagoshima) occurred in Shirasu deposits, and most of these were shallow failures (Teramoto et al., 2006). The dominance of these shallow, planar landslides in Shirasu is attributed to the rapid weathering of this unwelded material on steep slopes, thereby promoting repeated removal of the surficial weathered layer (Shimokawa et al., 1989; Yokota and Iwamatsu, 1999; Chigira and Yokoyama, 2005). The shallowest of these planar failures occur on the steepest slopes (Haruyama, 1974; Sako et al., 2000; Teramoto et al., 2006). Deeper rotational or planar landslides are much less frequent in Shirasu deposits and typically occur in more deeply weathered mantles and on gentler slopes. These previous reports suggest that the types of landslides in Shirasu are associated with rainfall patterns.

As with other mass failures, the internal hydrological processes and dominant flow pathways with respect to soil moisture conditions may dictate the timing, mode, and type of failure in Shirasu deposits (e.g., Bogaard et al., 2000; Jitousono et al., 2002: Sidle and Ochiai, 2006). Unweathered or slightly weathered Shirasu is rather strong in the dry state and supports slope gradients $>60^{\circ}$. However, water ingress rapidly weakens Shirasu, creating instabilities during periods of rainfall (Haruyama, 1974). Many slope failures in very steep Shirasu deposits have been attributed to the increased weight of this highly porous material during progressive rainfall, along with the associated loss of suction and thus reduced soil strength (Sako et al., 2000; Kitamura et al., 2003; Chigira and Yokoyama, 2005). Other landslides in Shirasu are triggered by the build-up of positive pore water pressure at depth during storms, sometimes affected by soil piping (Haruyama, 1974; Teramoto et al., 2006). Earthquakes also initiate occasional landslides in these deposits (Kubota and Omura, 2006). Once a landslide occurs, the surface Shirasu rapidly weathers, facilitating another landslide occurrence within decades to several hundreds of years (Shimokawa et al., 1989; Yokoto and Iwamatsu, 2000).

The timing of landslide occurrence with respect to storm duration, intensity, and antecedent precipitation is critical (e.g., Guzzetti et al., 2004). For instance, shallow rapid failures typically occur during large precipitation events with a period of high intensity (e.g., Sidle and Swanston, 1982; Terlien, 1997), while storm duration and total accumulation of water in the regolith is often more important for the initiation of deeper failures (e.g., Keefer and Johnson, 1983; Simoni et al., 2004). Therefore, the timing of landslide occurrence relative to precipitation inputs is a key factor for understanding the hydrogeomorphic processes that trigger different types of slope failures. Thus, the objectives of this study are to (1) investigate the range of landslide types that occur in Shirasu based on archived data and field inspections, and (2) develop relationships between rainfall characteristics and the timing of landslides. We obtained detailed data for occurrence time of landslides based on surveys by local government offices and analyzed the full range of landslide types 


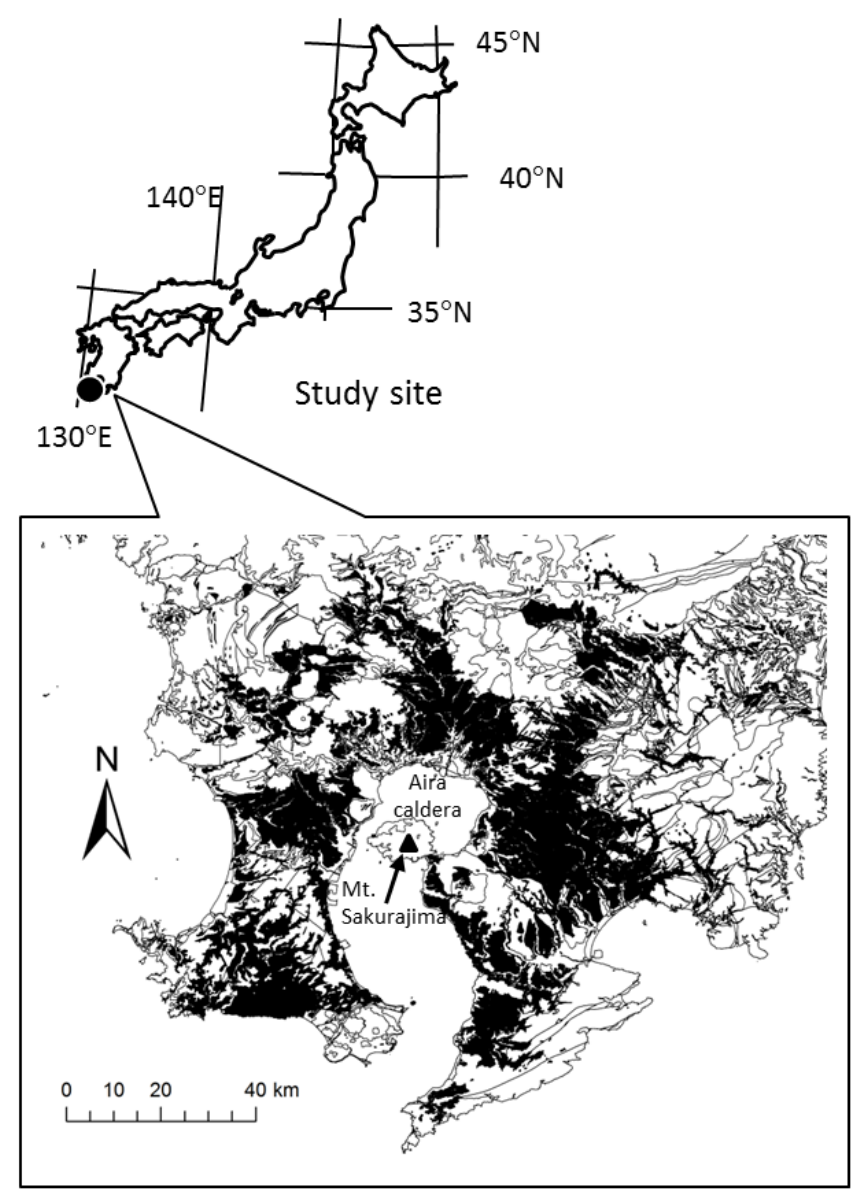

Figure 1. Study site showing the distribution of Shirasu deposits.

in this database. Triggering mechanisms of different types of landslides that we explored include analyses of rainfall amount, intensity, duration, and antecedent precipitation index (API). Our findings are aimed at developing prediction methods for different landslide types and resultant sediment disasters in terrain formed by unwelded pyroclastic flow deposits.

\section{Study site, historical context, and methods}

This study was conducted in areas covered by Shirasu deposits in Kagoshima, southern Kyushu, Japan (Fig. 1). The active volcano Sakurajima is located in Kagoshima Bay just south of the city of Kagoshima. Climate in this area is subtropical and humid, with no real dry season. Precipitation is heaviest during the warm months of June and July and least during December and January. Record high and low annual precipitation values were $4044 \mathrm{~mm}$ in 1993 and $1398 \mathrm{~mm}$ in 1894; mean annual precipitation is $2265 \mathrm{~mm}$. No significant trends in annual, June, or July precipitation since 1883 were found. Mean annual temperature at Kagoshima WMO station is $17.3{ }^{\circ} \mathrm{C}$, with minimum and maximum values of $15.5^{\circ} \mathrm{C}$

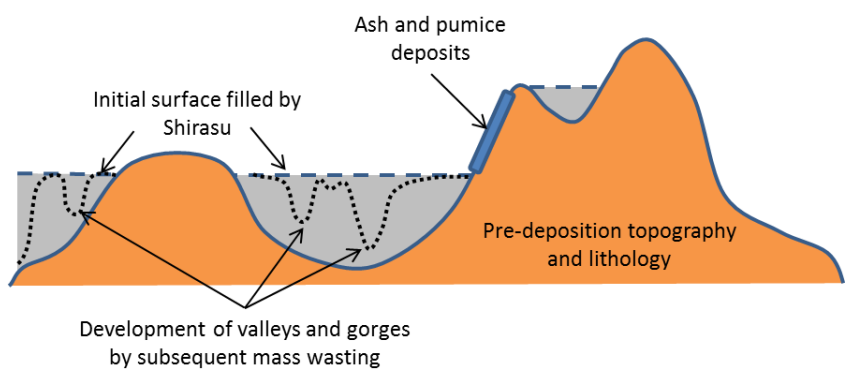

Figure 2. Schematic illustration of the dominant deposition patterns of pyroclastic materials (Shirasu) and the subsequent hydrogeomorphic processes that induced various types of sediment movements.

(in 1917) and $19.8^{\circ} \mathrm{C}$ (in 1998), respectively. There has been a significant increase in mean annual temperature of about $2.3^{\circ} \mathrm{C}$ over the 130 -year period or about $0.0176^{\circ} \mathrm{C} \mathrm{yr}^{-1}$.

The Shirasu deposits derived from Ito pyroclastic flows are concentrated in an arc that surrounds Kagoshima Bay where they originated from the Aira caldera (Fig. 1). These deposits filled the dissected valleys around Kagoshima up to an altitude of about $400 \mathrm{~m}$ and formed a plateau (Yokoyama, 1970; Miyagi, 1977). Evidence suggests that these pyroclastic flow deposits have not been affected by any crustal movement after emplacement (Yokoyama, 1970). Because of the highly erodible nature of these deposits, it is believed that they were dissected within less than 1500 years after initial deposition (Yokoyama, 1999). The mid-Holocene transgression of sea level resulted in coastal erosion of these deposits, while inland deposits continued to be eroded by mass wasting and fluvial processes in steep slopes and incised valleys. A conceptual illustration of the past and contemporary volcanic and hydrogeomorphic processes that have sculpted this terrain is given in Fig. 2, based on information provided by Yokomama (1970) and others.

The present area of southern Kyushu covered by unwelded pyroclastic flow deposits contains erosional remnants including isolated buttes and mesas with shallow landslides along the margins (Fig. 3a). Large, incised valleys have eroded into deep Shirasu deposits with mass failures along the steep inner gorges (Fig. 3d). In the valleys where landslide deposits accumulate, there is a risk of future debris flows once a critical level of sediment accumulates, together with the occurrence of a large runoff event (e.g., Benda and Dunne, 1997; Sidle and Ochiai, 2006). Although Haruyama (1974) classified eight types of landslides in Shirasu deposits, most of these landslides can be categorized into two types based on the depth of failure. We define these two types as (1) shallow ( $<1 \mathrm{~m}$ deep) "slab-type" failures on very steep slopes (Fig. 3b), and (2) slightly deeper (one to several meters deep) planar landslides on less steep slopes (Fig. 3c). The slab-type failures in these highly porous deposits occur at high frequencies, whereas the deeper landslides in Shirasu are less frequent. The mean gradient of slab-type failures is $>71^{\circ}$ 


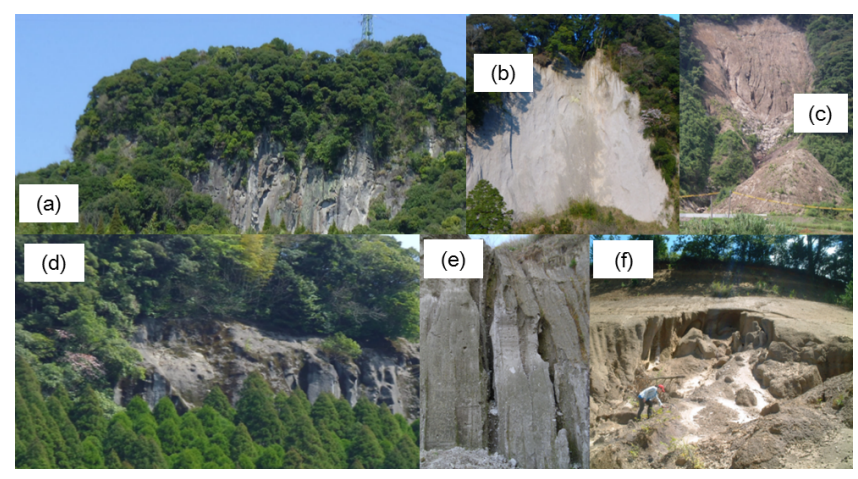

Figure 3. Characteristics of geomorphic features in Shirasu areas: (a) isolated buttes and mesas with active mass wasting along margins; (b) slab-type failures on steep slopes; (c) slightly deeper planar failures on less steep slopes; (d) shallow landslides along inner valley gorges; (e) shallow piping phenomena; and (f) soil piping and subsequent gully formation.

and slope lengths range from about 20 to $100 \mathrm{~m}$. Occurrence of slab-type failures is influenced by increased mass due to long-term rainfall and decreased matric suction or by a combination of both mechanisms. Slightly deeper landslides (one to several meters in depth) occurred on slope gradients ranging from 37 to $46^{\circ}$. These deeper landslides are typically triggered by rainfall infiltration and possibly the influence of pipeflow causing a positive pore pressure to develop during storm events (e.g., Teramoto et al., 2006; Taniguchi, 2008). However, these landslides can also be influenced or caused by increased weight due to accumulated rainwater and loss of matric suction (e.g., Chigira and Yokoyama, 2005; Fukuda, 2011). These deeper landslides cause considerably more damage. As noted by others (Haruyama, 1974; Jitousono et al., 2002), we found evidence of soil piping in both types of landslides (Fig. 3e, f).

Physical and mineralogical properties of Shirasu are presented in Table 1. The rapidly weathered soil mantle has little structure with porosity values often exceeding $60 \%$ and bulk density values often $<1 \mathrm{~g} \mathrm{~cm}^{-3}$ (Yokoyama, 1970; Chigira and Yokoyama, 2005). Due to the dominance of sand-sized material, Shirasu has a relatively narrow particle size range - about half of the mass is within the 0.125 to $1.0 \mathrm{~mm}$ range (Iwamatsu et al., 1989). The small clay content often contains halloysite, a clay mineral typically associated with unstable soils (Chigira and Yokoyama, 2005; Sidle and Ochiai, 2006). Cohesion values have been reported up to $10 \mathrm{kPa}$, and internal angle of friction is comparable to other similar materials (Umehara et al., 1975; Sako et al., 2000; Chigira and Yokoyama, 2005). Distinct hydrological pathways (including soil pipes) and processes occur in Shirasu deposits because of the high porosity and low density of the soil (Haruyama, 1974; Jitousono et al., 2002).

Land cover in rural regions of Kagoshima where unwelded pyroclastic flow deposits exist consists of mixed broadleaf
Table 1. Physical and mineralogical characteristics of Shirasu based on the following sources: Yokoyama (1970), Umehara et al. (1975), Nakano et al. (1981), Iwamatsu et al. (1989), Sugio and Okabayashi (1994), Sako et al. (2000), Chigira and Yokoyama (2005), Hira et al. (2006), and Takewaka (2007). * indicates average values.

\begin{tabular}{|c|c|}
\hline Percent sand & $77 \% *$ \\
\hline Percent silt & $20 \% *$ \\
\hline Percent clay & $3 \% *$ \\
\hline Porosity (\%) & $44-65 \%$ \\
\hline Particle density $\left(\mathrm{Mg} \mathrm{m}^{-3}\right)$ & $2.3-2.55$ \\
\hline Bulk density $\left(\mathrm{Mg} \mathrm{m}^{-3}\right)$ & $0.9-1.2$ \\
\hline Cohesion $(\mathrm{kPa})$ & $0-10$ \\
\hline Internal angle of friction $\left({ }^{\circ}\right)$ & $30-40^{\circ}$ \\
\hline Saturated hydraulic conductivity $\left(\mathrm{ms}^{-1}\right)$ & $10^{-5}-10^{-6}$ \\
\hline $\mathrm{SiO}_{2}$ content & $70 \% *$ \\
\hline $\mathrm{Al}_{2} \mathrm{O}_{3}$ content & $14 \% *$ \\
\hline Alkali oxide content & $8 \% *$ \\
\hline
\end{tabular}

forests, Japanese cedar and cypress plantations, and interspersed agricultural areas (Fig. 3). On the steepest slopes, where repeated slab-type failures occur, little vegetation develops (Fig. 3a, b). Because the government databases we used focused on landslide damage, a large extent of the landslides reported herein occurred in urban and residential areas.

Landslide inventories from 1985 to 2005 were obtained via surveys conducted by the Erosion and Sedimentation Control Division and Forest Management Division of Kagoshima. Among these data, landslides with clearly defined occurrence times were selected for further analysis. We then overlayed the locations of these landslides onto digital topographic and geologic maps with scales of $1: 200000$ to ascertain which landslides occurred in Shirasu areas. In total, 184 Shirasu landslides with complete information (i.e., accurate dates, times, locations, and rainfall records) were selected from the 1153 landslides recorded from 1985 to 2005 (Fig. 4). It should be noted that this landslide database is not comprehensive, because the agencies conducting these surveys focused on damage caused by landslides, thus few slope failures were reported in undeveloped rural areas. Additionally, records with complete data from 1985 to 1999 were sparse, thus all but 14 of the landslides in our database are from the 2000 to 2005 period. More than one-third of these reported landslides occurred in the city of Kagoshima (rectangle in Fig. 4) indicating the focus on damage assessments. We conducted field investigations at selected landslide sites.

Rainfall information for events that triggered the landslides was compiled from AMeDAS (Automated Meteorological Data Acquisition System by the Japanese Meteoro- 


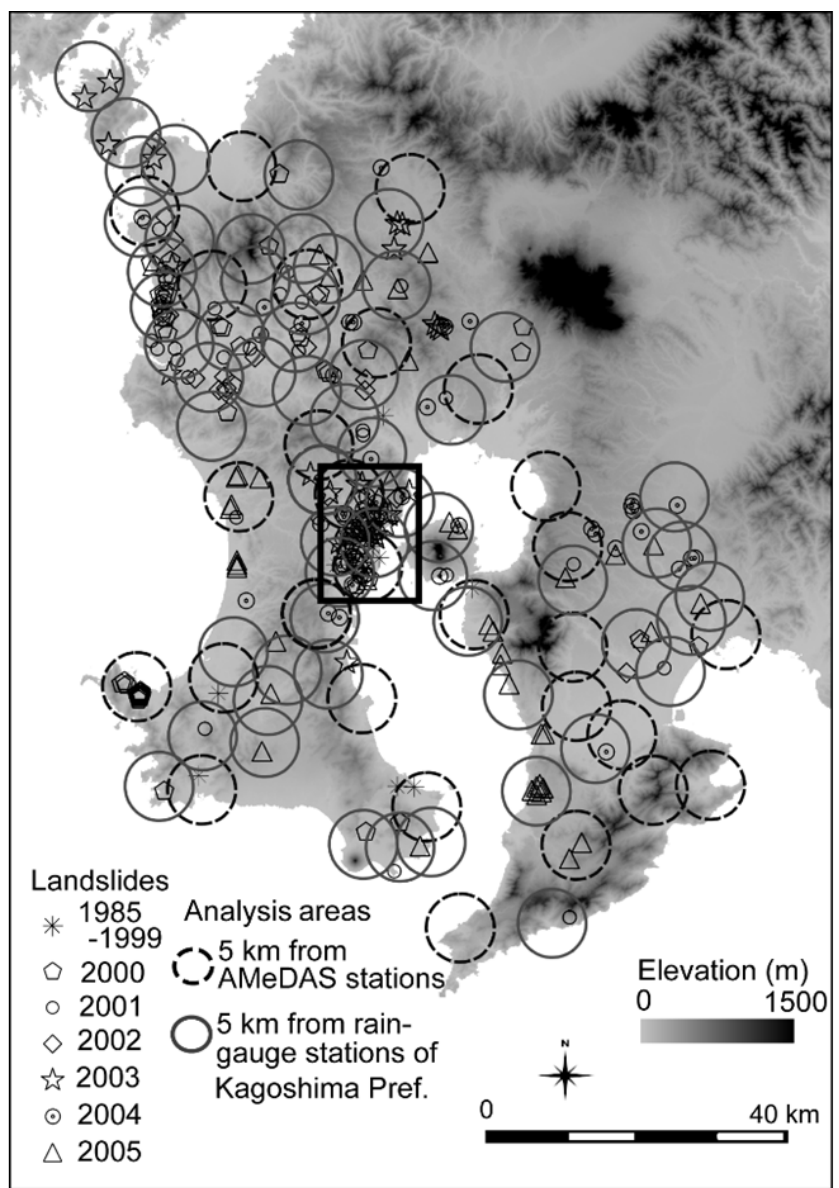

Figure 4. Locations of the Shirasu landslides in our database from 1985 to 2005 together with rain gauge stations in Kagoshima. Rectangle shows the concentration of more than one-third of these damaging landslides in the city of Kagoshima.

logical Agency) and rain gauges operated by Kagoshima prefecture. As a further criterion for landslide selection, we only chose landslides with rainfall records within $5 \mathrm{~km}$. We compiled the following rainfall parameters: (1) total storm precipitation; (2) storm duration; (3) average storm intensity; (4) total event precipitation until the occurrence of the landslide (also, duration and average intensity during this period); and (5) antecedent precipitation index (API) for both 7- and 30-day periods ( $\mathrm{API}_{7}$ and $\mathrm{API}_{30}$, respectively). In our reported API values, we subtracted the mean evapotranspiration rate in southern Kyushu $\left(2.6 \mathrm{mmd}^{-1}\right.$; Takagi, 2013) from API for the period of assessment (i.e., 7 or 30 days). $\mathrm{API}_{7}$ reflects soil moisture conditions in the near-surface layer, while $\mathrm{API}_{30}$ represents moisture conditions deeper in the soil profile (Sidle et al., 2000). Additionally, we used a simple infinite slope model to calculate the effects of increases in water content (i.e., weight) and decreases in cohesion (i.e., via loss of suction) on the stability of steep Shirasu slopes.

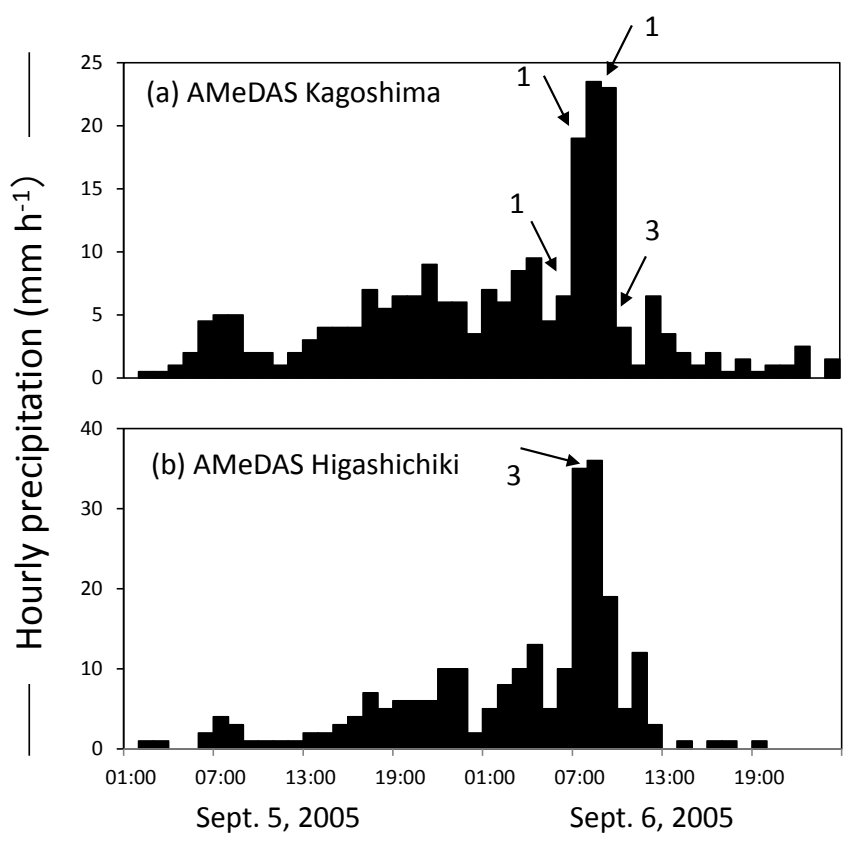

Figure 5. Examples for rainfall hyetographs in two locations of Kagoshima showing the occurrence of landslides during typhoon Nabi, 5-6 September 2005. Arrows and values indicate the timing and numbers of landslides, respectively.

\section{Results}

\subsection{Overview of rainfall conditions that triggered landslides}

We documented 184 landslides in Shirasu deposits from 1985 to 2005 that occurred on 57 separate days. In many cases, the landslides that occurred on the same days were triggered by somewhat different rainfall conditions due to location. In all cases we used the AMeDAS rainfall record closest to the landslide site for subsequent analysis. From 2001 to 2005 , between 23 and 52 landslides were reported annually in the database; earlier years had less complete records. Detailed information on the occurrence of landslides showed that the timing of failures varied depending on location. For instance, during the 5-6 September 2005 storm, some landslides occurred during or just before the onset of intense rainfall, while other landslides occurred just after intense rainfall (Fig. 5).

Wide ranges of rainfall and API triggered landslides. Total storm duration and duration up to landslide occurrence ranged from 5 to 271 and 2.5 to $141 \mathrm{~h}$, respectively. Average storm intensity for the entire storm and during the period up to landslide initiation ranged from 1.3 to 28.6 and 0.3 to $32 \mathrm{~mm} \mathrm{~h}^{-1}$, respectively. Total storm precipitation and cumulative precipitation up until the landslide ranged from 45 to 650 and 4 to $621 \mathrm{~mm}$, respectively. Maximum $1 \mathrm{~h}$ intensity of storms that triggered landslides ranged from 7 to $80 \mathrm{~mm} \mathrm{~h}^{-1}$. 

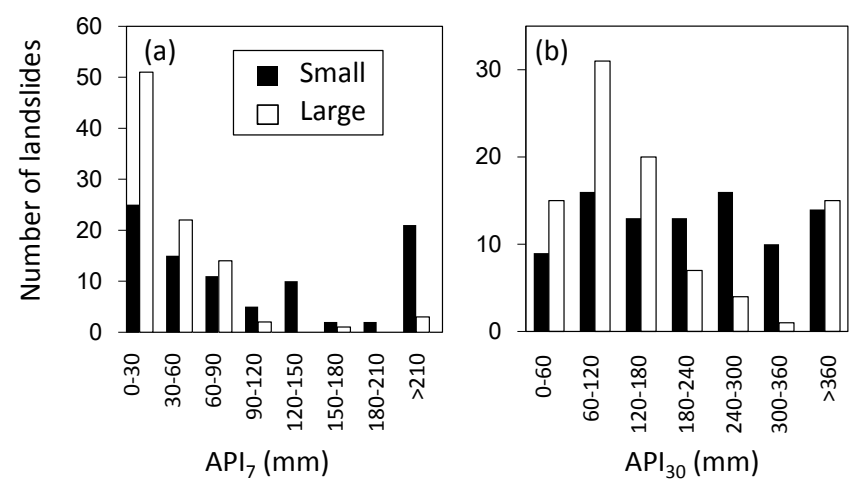

Figure 6. Distributions of small $(\leq 200 \mathrm{~mm}$ of storm precipitation up until the occurrence of the landslide) and large ( $>200 \mathrm{~mm}$ precipitation until the landslide) storms that triggered landslides for different levels of adjusted $\mathrm{API}_{7}$ (a) and $\mathrm{API}_{30}$ (b).

\subsection{Storm size, antecedent rainfall, and landslide initiation}

We categorized the 184 landslides into storms with large $(>200 \mathrm{~mm})$ and small $(\leq 200 \mathrm{~mm})$ total amounts of rainfall up to the occurrence of landslides. Both $\mathrm{API}_{7}$ and $\mathrm{API}_{30}$ for large $(>200 \mathrm{~mm})$ storms that triggered landslides were much lower than for smaller $(\leq 200 \mathrm{~mm})$ storms (Fig. 6). For example, of the 93 large storms, $78.5 \%$ had $\mathrm{API}_{7} \leq 60 \mathrm{~mm}$; only $4 \%$ of these larger storms had $\mathrm{API}_{7}>150 \mathrm{~mm}$. In contrast, of the 91 smaller storms, $56 \%$ had $\mathrm{API}_{7}>60 \mathrm{~mm}$. Similarly, $71 \%$ of large storms that triggered landslides had $\mathrm{API}_{30} \leq 180 \mathrm{~mm}$, while only $41 \%$ of the small storms had $\mathrm{API}_{30} \leq 180 \mathrm{~mm}$. In particular, both the high number of landslides that occurred during smaller storms when API indices were high (i.e., $\mathrm{API}_{7}>210 \mathrm{~mm}$ and $\mathrm{API}_{30}>240 \mathrm{~mm}$ ) and the even larger number of landslides that occurred during large storms when API indices were low to moderate (i.e., $\mathrm{API}_{7}<90 \mathrm{~mm}$ and $\mathrm{API}_{30}<120 \mathrm{~mm}$ ) have strong implications for landslide-triggering mechanisms that will be discussed later (Fig. 6).

\subsection{Storm precipitation-duration relationships associated with landslide initiation}

Relationships between total storm precipitation and storm duration (both up until the occurrence of landslides) were established for relatively low $\left(\leq 5 \mathrm{~mm} \mathrm{~h}^{-1}\right)$ and higher $\left(>5 \mathrm{~mm} \mathrm{~h}^{-1}\right)$ intensity events. For each of these populations, total storm precipitation was significantly correlated to the respective storm duration ( $p>0.01 ; R^{2}$ values ranged from 0.73 to 0.74 ) (Fig. 7). Higher intensity storms $\left(>5 \mathrm{~mm} \mathrm{~h}^{-1}\right)$ that triggered landslides were shorter in duration and the slope of the cumulative precipitation versus storm duration line was more than twice as steep as the slope of the lower intensity $\left(<5 \mathrm{~mm} \mathrm{~h}^{-1}\right)$ line. These differences suggest that

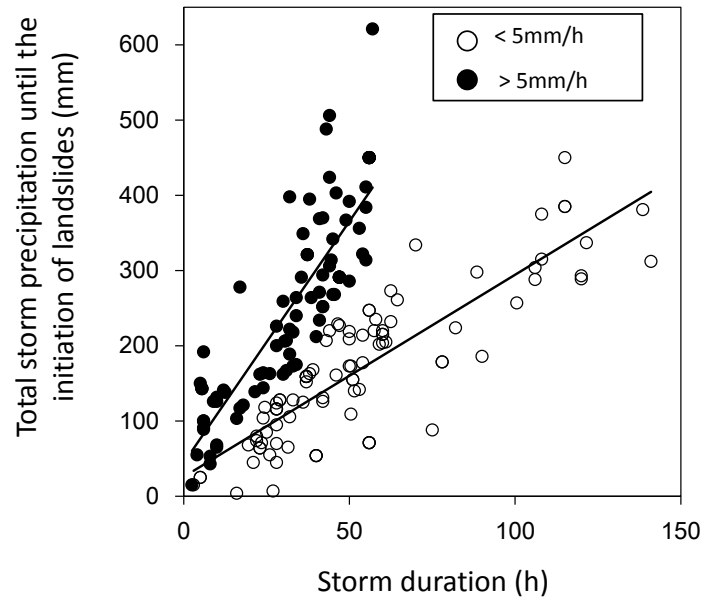

Figure 7. Storm rainfall-duration relationships with average intensities $>5$ and $\leq 5 \mathrm{mmh}^{-1}$.

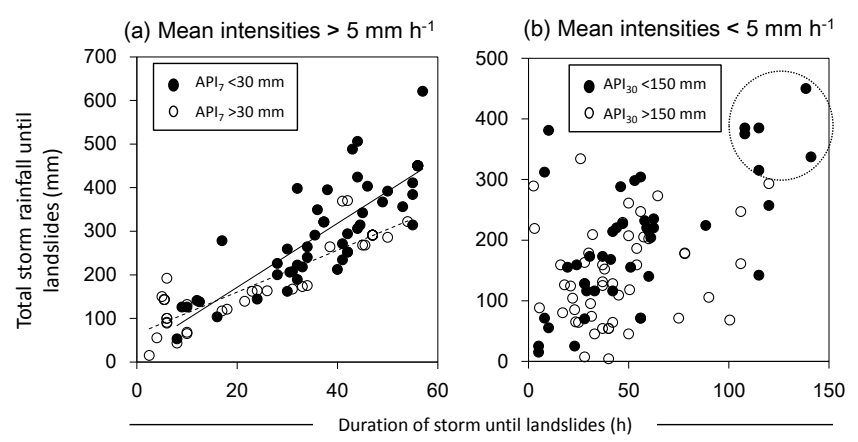

Figure 8. Total storm rainfall-duration relationships with different API conditions: (a) mean intensities $>5 \mathrm{mmh}^{-1}$ (b) mean intensities $>5 \mathrm{mmh}^{-1}$; the dashed circle indicates six large and long duration events that probably triggered landslides due to an accumulation of pore water pressure during the individual storms.

different landslide types and mechanisms may be associated with the two populations.

To further analyze these relationships between cumulative precipitation and storm duration up until landslide occurrence, we examined whether API helped discriminate causal effects in both the $>5 \mathrm{~mm} \mathrm{~h}^{-1}$ and $\leq 5 \mathrm{~mm} \mathrm{~h}^{-1}$ storm populations. For the 93 storms with average intensities $>5 \mathrm{~mm} \mathrm{~h}^{-1}$, we used values of $\mathrm{API}_{7} \leq 30 \mathrm{~mm}$ and $>30 \mathrm{~mm}$ to differentiate between drier and wetter antecedent conditions, respectively. Both of these API subclasses had significant correlations between storm precipitation and duration $\left(p>0.01 ; R^{2}=0.70\right.$ and 0.80 , respectively), and, for storm durations $>20 \mathrm{~h}$, the $\mathrm{API}_{7} \leq 30 \mathrm{~mm}$ events generally required substantially more cumulative rainfall to trigger a landslide compared to storms preceded by $\mathrm{API}_{7}>30 \mathrm{~mm}$ (Fig. 8a).

It was more difficult to segregate the 91 landslidetriggering storms with low average intensity $\left(\leq 5 \mathrm{~mm} \mathrm{~h}^{-1}\right)$ using an $\mathrm{API}_{30}$ threshold. While relationships between cu- 
mulative precipitation and storm duration up until landslide occurrence were poorly correlated $\left(R^{2}=0.41\right.$ and 0.047 for $\mathrm{API}_{30} \leq 150 \mathrm{~mm}$ and $\mathrm{API}_{30}>150 \mathrm{~mm}$, respectively; Fig. 8b), during multi-day storms, the $\mathrm{API}_{30} \leq 150 \mathrm{~mm}$ events generally required substantially more cumulative rainfall to trigger a landslide compared to storms preceded by $\mathrm{API}_{30}>150 \mathrm{~mm}$. Six storms with $\mathrm{API}_{30}<150 \mathrm{~mm}$ and high event rainfall $(\geq 315 \mathrm{~mm})$ prior to slope failure are highlighted in Fig. 8b for later discussion.

\subsection{Effects of changes in weight and cohesion due to accumulated rainfall}

To better understand how shallow, slab-type failures and slightly deeper landslides in Shirasu are affected by increased weight and loss of suction during periods of progressive wetting, we assessed scenarios of how changes in these conditions may influence slope stability. Two cases were examined, one with shallow soils $(0.5 \mathrm{~m})$ and very steep slope gradient $\left(72^{\circ}\right)$ typical of slab-type failures, and another with slightly deeper soils $(1 \mathrm{~m})$ and a slope gradient of $40^{\circ}$ (typical gradient for this type of failure). Firstly, we examined only the effects of increased soil weight due to rainwater accumulation (total amount of rain water stored in the soil) on the stability of these pyroclastic flow deposits and then assessed the effects of both increased soil weight and the concurrent loss of cohesion (suction decrease). These two factors may contribute to slope failure even in the absence of a positive pore pressure developing within the soil mantle.

Slope stability for the two scenarios described was assessed using a model that assumes a homogenous, infinite slope (e.g., Sidle and Swanston, 1982):

$\mathrm{FS}=\frac{C+\left(\gamma_{\mathrm{f}} d \cos ^{2} \alpha-u\right) \tan \phi}{\gamma_{\mathrm{f}} d \cos \alpha \sin \alpha}$,

where FS is the factor of safety (FS $\leq 1$ indicates conditions of failure), $\gamma_{\mathrm{f}}$ is the unit weight of soil at field moisture $\left(\mathrm{kN} \mathrm{m}^{-3}\right), d$ is the vertical soil depth $(\mathrm{m}), C$ is soil cohesion ( $\mathrm{kPa}), \alpha$ is slope gradient (degrees), $\phi$ is internal angle of friction (degrees), and $u$ is pore water pressure ( $\mathrm{kPa}$, set to zero in these unsaturated examples).

All parameters selected for these analyses are based on data for Shirasu soils in southern Kyushu (Table 1). In calculations, unit soil weight was allowed to vary from totally dry $\left(\gamma_{\mathrm{f}}=9.32 \mathrm{kN} \mathrm{m}^{-3}\right)$ up to near-saturated conditions $\left(\gamma_{\mathrm{f}}=14.81 \mathrm{kN} \mathrm{m}^{-3}\right)$ and calculated weight increases with increasing moisture content. Internal angle of friction $(\phi)$ was assumed to be $32^{\circ}$. In simulations of both site conditions, cohesion was determined as a function of soil suction described by an exponential distribution fitted to Sako et al.'s (2000) Shirasu data. Soil suction was related to water content via a simple $\log -\log$ function that fit these data. Alternatively, soil cohesion was considered static $(C=5 \mathrm{kPa})$ for both cases to assess only the effects of increased soil weight. In these calculations, the increased weight of rainwater alone (a) Depth $=0.5 \mathrm{~m}$, Gradient $=72^{\circ}$

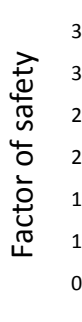

3.8
3.3
2.8
2.3
1.8
1.3
0.8

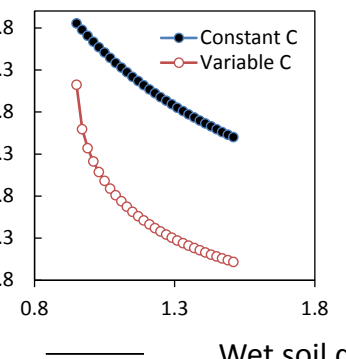

(b) Depth $=1 \mathrm{~m}$, Gradient $=40^{\circ}$

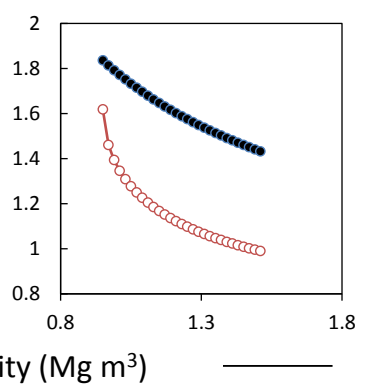

Figure 9. Changes in factor of safety of Shirasu hillslopes with increases in wet density with constant cohesion $(C=5 \mathrm{kPa})$ and cohesion as a function of soil suction (Sako et al., 2000). Two slope stability cases are considered: (a) shallow slip surface $(d=0.5 \mathrm{~m})$ mantle on very steep slopes $\left(72^{\circ}\right)$; and (b) deeper slip surface $(d=1 \mathrm{~m})$ on $40^{\circ}$ slopes.

decreases FS by 1.35 for shallow soils on steep slopes (slabtype failures) and by 0.41 for the deeper soils going from driest to wettest conditions (Fig. 9). However, if the effects of reduced cohesion are also included, FS declines more rapidly during initial wetting and ultimately approaches failure conditions $(\mathrm{FS}=1)$ in both slope conditions as the soil reaches saturation (Fig. 9). Clearly the combined loss of suction and increase in soil weight play a role in destabilizing both types of hillslopes, but the amount of reduction in FS is much greater in the potential steep, slab-type failures. Nevertheless, in many cases, it may also be necessary for a positive pore water pressure to develop to induce slope failure. For lower values of $C$, FS would be reduced further, but the effect of suction loss with progressive wetting would be less.

\subsection{Analysis of rain intensity-duration thresholds for Shirasu landslides}

To illustrate the importance of API on certain types of landslides in unwelded pyroclastic flow deposits, we employ typical rainfall intensity-duration threshold analysis. Caine (1980) developed a relationship between mean rainfall intensity and storm duration based on 73 events worldwide that triggered landslides and debris flows. The lower bound of this relationship, above which most landslides occur is

$I=14.82 D_{\mathrm{s}}^{-0.39}$,

where $I$ is the mean storm intensity $\left(\mathrm{mmh}^{-1}\right)$ and $D_{\mathrm{s}}$ is the storm duration (h). Sidle and Ochiai (2006) modified this general relationship by excluding very short and long duration events and including additional data:

$I=13.58 D_{\mathrm{s}}^{-0.38}$.

Such thresholds are useful for establishing the minimum rainfall inputs that trigger landslides and debris flows. Here 


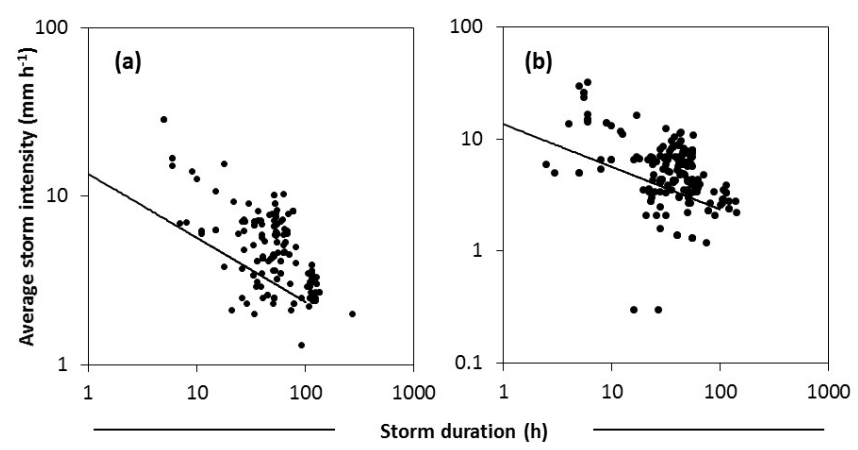

Figure 10. Average storm intensity-duration $(I-D)$ relationships for the events that triggered landslides plotted along with the lower landslide threshold based on Eq. (3) (Sidle and Ochiai, 2006). (a) I$D$ relationships for the entire storm event; and (b) $I-D$ relationships for average intensity and duration from the onset of the storm until landslide occurrence.

we plot the average intensity-duration data for all 184 rainfall events that triggered landslides in Shirasu deposits and compare these with Eq. 3 to help understand the conditions that caused slope failure. First, we used average storm intensity and total storm duration (not the values for rainfall up until the landslide occurrence) to be consistent with the data used to develop Eqs. (2) and (3) (Fig. 10a).

While many landslide-producing storms are plotted above or near the Sidle and Ochiai (2006) threshold, 22 landslides were triggered by events that are plotted below the threshold (Fig. 10a). All of these storms had average intensities $<5 \mathrm{~mm} \mathrm{~h}^{-1}$ and all but one storm had $<200 \mathrm{~mm}$ of total rainfall. Only 3 of these 22 events had $\mathrm{API}_{30}$ values $<200 \mathrm{~mm}$ and more than half had $\mathrm{API}_{30}$ values $>300 \mathrm{~mm}$. Given that much of this water was stored in the porous Shirasu deposits prior to the triggering storms, most of these 22 landslides and some of the events positioned just above the threshold are likely influenced by the combined effects of the accumulated mass of rainfall and the associated loss of matric suction within these deposits.

When we plot average storm intensity up until landslide occurrence versus duration from the onset of the storm to the initiation of the landslide, 38 landslides were triggered by events that are plotted below the threshold (Fig. 10b). Only two of these storms had average intensities slightly $>5 \mathrm{~mm} \mathrm{~h}^{-1}\left(5.4-6.0 \mathrm{~mm} \mathrm{~h}^{-1}\right)$, and all storms had $<200 \mathrm{~mm}$ of total rainfall up until landslide occurrence. Seven of these 38 events had $\mathrm{API}_{30}$ values $<200 \mathrm{~mm}$ and more than half had $\mathrm{API}_{30}$ values $>300 \mathrm{~mm}$. Total storm precipitation for all of these events was $<200 \mathrm{~mm}$. These criteria provide a more liberal estimate of the landslides that were affected by increased weight and loss of suction.

\section{Empirical criteria for different landslide-triggering mechanisms}

Based on our analyses and understanding of threshold behavior for different types of landslides, the following empirical criteria are proposed to identify landslides triggered primarily by pore water pressure during individual large storms: $\mathrm{API}_{30} \leq 60 \mathrm{~mm}$, average storm intensity $>5 \mathrm{~mm} \mathrm{~h}^{-1}$, and duration $<20 \mathrm{~h}$ (Fig. 11). When $\mathrm{API}_{30}$ values were $\leq 60 \mathrm{~mm}$, it is unlikely that increases in mass and decreases in suction due to accumulated soil water would be significant landslide trigger mechanisms. Additionally, an average storm intensity of $5 \mathrm{~mm} \mathrm{~h}^{-1}$ provides a good segregation criterion for landslide populations based on total precipitation-duration plots (Fig. 7). Of the 93 landslide events during large storms, 40 occurred when $\mathrm{API}_{30} \leq 60 \mathrm{~mm}$ and average storm intensity $>5 \mathrm{~mm} \mathrm{~h}^{-1}$, thus strongly suggesting rapid pore water pressure response as the cause. Additionally, the six large, lower intensity storms highlighted in Fig. 8b (total precipitation $>300 \mathrm{~mm}$ and average intensities $\leq 5 \mathrm{~mm} \mathrm{~h}^{-1}$ ) likely triggered landslides due to positive pore pressure response. For the smaller storm category $(\leq 200 \mathrm{~mm})$, we can assume that higher average intensities $\left(>10 \mathrm{~mm} \mathrm{~h}^{-1}\right)$, together with $>75$ and $\leq 200 \mathrm{~mm}$ of rainfall up until slope failure, will trigger landslides by positive pore pressure response during storms (Fig. 11). These criteria account for 14 landslide events from the small storm category that could be triggered by positive pore pressure. In cases where API values are high, it is difficult to use API to separate landslide-producing storms in which the trigger mechanism was the combined increase in soil mass and loss of suction from those triggered by positive pore water pressure because many of these events were large enough to initiate landslides via positive pore pressure accretion alone. During smaller storms, and especially less intense storms, landslides are likely caused by a combined increase in soil mass and loss of suction when $\mathrm{API}_{30}$ is high. These triggering mechanisms are supported by the intensityduration analyses (Fig. 10).

The various precipitation criteria that influence landslidetriggering mechanisms in Shirasu deposits are outlined in Fig. 11 together with the site and resultant landslide characteristics (e.g., depth to failure plane and landslide size). Our analyses could not account for soil piping effects, as this was not noted in the landslide records.

\section{Summary and conclusions}

Our study lends insights into the relationships between rainfall characteristics and different types of landslides in unwelded pyroclastic flow deposits. These Shirasu landslides inflict heavy damage every year in southern Kyushu during the storm seasons. Two distinct rainfall conditions trigger different types of landslides in Shirasu deposits. The first scenario involves long-term (i.e., weeks) accumulated rainfall 


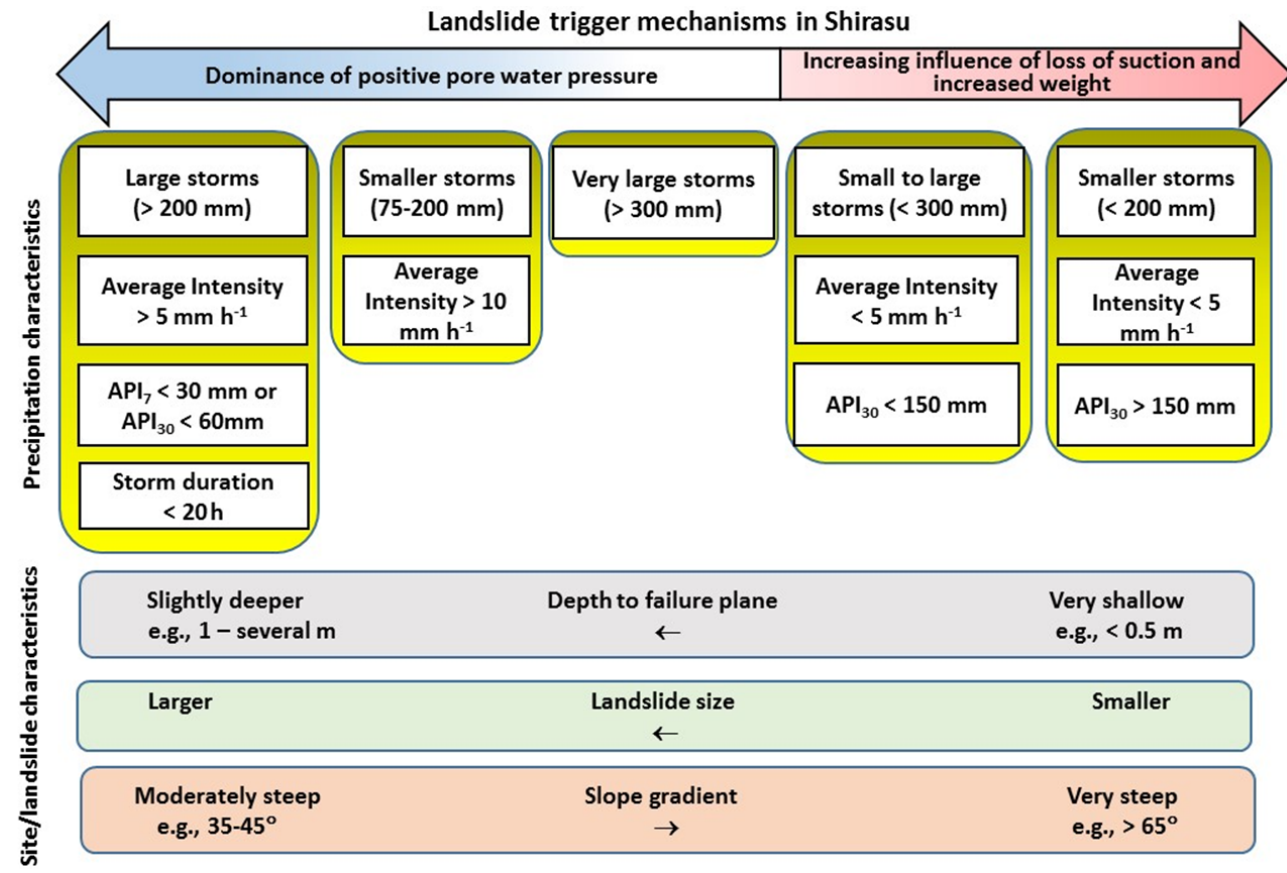

Figure 11. Diagram of empirical precipitation criteria that affect different landslide-triggering mechanisms in Shirasu deposits in southern Kyushu, together with slope gradient and resultant landslide characteristics.

stored in highly porous Shirasu on very steep slopes (often $>60^{\circ}$ ) followed by a small to large rain event with typically low intensity. This antecedent moisture together with the additional mass of event rain and the associated decrease in matric suction tends to promote slab-type and other shallow failures ( $>1 \mathrm{~m}$ depth) in highly weathered Shirasu. These failures have a high frequency of recurrence as exposed material weathers rapidly promoting a new failure within the weathered rind (Shimokawa et al., 1989). In the second rainfall scenario, shorter duration, higher intensity storms with large total precipitation up until landslide occurrence trigger slightly deeper ( $>1 \mathrm{~m}$ depth) landslides via pore water pressure response at a hydrologic discontinuity (i.e., weatheredunweathered Shirasu boundary) or by piping mechanisms. These slightly deeper landslides are typically larger, occur on somewhat gentler slopes, and initiate as the result of individual storm events. They can be influenced by shorter term antecedent precipitation as well.

For the 184 landslide events in our database, antecedent precipitation was clearly lower for large $(>200 \mathrm{~mm})$ landslide-producing storms compared to smaller $(\leq 200 \mathrm{~mm})$ storms, lending support to the importance of the influence of long-term API (increasing mass and reducing suction) on shallow (slab-type) failures. Additionally, two clear populations of landslides in Shirasu emerged from the total storm precipitation-duration relationship: those triggered by storms with average intensities up until landslide occurrence of $>5 \mathrm{mmh}^{-1}$ and those triggered by storms with average intensities $\leq 5 \mathrm{mmh}^{-1}$ (Fig. 7). Further inspec- tion based on antecedent precipitation provided additional insights into landslide responses. For higher average intensity $\left(>5 \mathrm{mmh}^{-1}\right)$ storms, $\mathrm{API}_{7} \leq 30 \mathrm{~mm}$ was useful to identify landslides triggered by rapid pore water pressure response, especially for shorter $(>20 \mathrm{~h})$ duration events (Fig. 8a). Landslides that initiated during low intensity $\left(\leq 5 \mathrm{~mm} \mathrm{~h}^{-1}\right)$ storms were strongly influenced by increased mass and loss of suction associated when $\mathrm{API}_{30}$ values were $>150 \mathrm{~mm}$ (Fig. 8b). Even for the low intensity events with $\mathrm{API}_{30} \leq 150 \mathrm{~mm}$, only about six landslides were attributed specifically to positive pore pressure accretion during the event - these occurred during large $(>300 \mathrm{~mm})$ storms; the remaining landslides were likely influenced in part by accumulated mass due to prior rainfall as well as loss of suction.

The results of this study show that different storm and antecedent precipitation conditions need to be considered in predicting the occurrence of different types of landslides in Shirasu deposits. This new information is quite valuable for sediment disaster prevention, including real-time warning systems, and the empirical precipitation criteria for different Shirasu landslide characteristics outlined in Fig. 11 should be useful in this regard. Because Shirasu is a typical unwelded ignimbrite, it has been noted that findings related to landslide precursors (weathering) and mechanisms can be reasonably extrapolated to other unwelded ignimbrites in humid regions (Chigira and Yokoyama, 2005). Nevertheless, any application of our results to other areas of unwelded pyroclastic flow deposits should carefully consider similarities and differences in weathering rates; climate; slope gradients; poros- 
ity; and other physical, hydrogeomorphic, and geotechnical properties prior to making such comparisons.

Acknowledgements. This paper is based primarily on Mika Yamao's graduate research at Disaster Prevention Research Institute, Slope Conservation Section, Kyoto University when all authors were employed there. We dedicate this paper to her memory and to her family. Rest in peace, Mika. Gratitude is expressed to Esturo Shimokawa for sharing his ideas and guiding us in the field, to T. Nosaka for his assistance in the field, and to Ram Ray, Emilia Damiano, Thom Bogaard, and an anonymous referee for their insightful review comments.

Edited by: T. Bogaard

Reviewed by: R. Ray, E. Damiano, and one anonymous referee

\section{References}

Aramaki, S.: Formation of the Aira caldera, southern Kyushu, $\sim 22,000$ years ago, J. Geophys. Res., 89, 8485-8501, doi:10.1029/JB089iB10p08485, 1984.

Benda, L. and Dunne, T.: Stochastic forcing of sediment supply to channel networks from landsliding and debris flow, Water Resour. Res., 33, 2849-2863, 1997.

Bernard, B., van Wyk deVries, B., and Leyrit, H.: Distinguishing volcanic debris avalanche deposits from their reworked products: the Perrier sequence (French Massif Central), B. Volcanol., 71, 1041-1056, 2009.

Bogaard, T. A., Antoine, P., Desvarreux, P., Giraud, A., and Van Asch, T. W. J.: The slope movements within Mondore's graben (Drôme, France); the interaction between geology, hydrology and typology, Eng. Geol., 55, 297-312, 2000.

Caine, N.: Rainfall intensity-duration control of shallow landslides and debris flows, Geograf. Ann., 62A, 23-27, 1980.

Chigira, M. and Yokoyama, O.: Weathering profile of non-welded ignimbrite and the water infiltration behaviour within it in relation to the generation of shallow landslides, Eng. Geol., 78, 187-207, 2005.

Cimarelli, C. and de Rita, D.: Deep-seated gravitational slope deformations in volcanic settings: examples from Italian volcanoes, Geografia Fisca E Dinamica Quaternaria, 33, 155-164, 2010.

Crosta, G. B. and Dal Negro, P.: Observations and modelling of soil slip-debris flow initiation processes in pyroclastic deposits: the Sarno 1998 event, Nat. Hazards Earth Syst. Sci., 3, 53-69, doi:10.5194/nhess-3-53-2003, 2003.

Dai, F. C. and Lee, C. F.: Terrain-based mapping of landslide susceptibility using a geographical information system: a case study, Can. Geotech. J., 38, 911-923, 2001.

De Falco, M., Di Crescenzo, G., and Santo, A.: Volume estimate of flow-type landslides along carbonatic and volcanic slopes in Campania (Southern Italy), Nat. Hazards, 61, 51-63, 2012.

Fukuda, T.: Real-time hazard mapping of Shirasu slope failure Kagoshima, Japan, Journal of Geosciences, Osaka City University, Japan, 54, 43-61, 2011.

Guzzetti, F., Cardinali, M., Reichenbach, P., Cipolla, F., Sebastiani, C., Galli, M., and Salvati, P.: Landslides triggered by the 23 November 2000 rainfall event in the Imperia Province, Western Liguria, Italy, Eng. Geol., 73, 229-245, 2004.
Haruyama, M.: Features of slope-movements due to heavy rainfalls in the Shirasu region of southern Kyushu, Memoirs of the Faculty of Agriculture, Kagoshima University, Japan, 10, 151-163, 1974.

Hira, M., Hashiguchi, K., Ueno, M., and Okayasu, T.: Deformation behaviour of Shirasu soil by the extended suloading surface model, Lowland Technology International, 8, 37-46, 2006.

Hürlimann, M., Ledesma, A., and Martí, J.: Characterisation of a volcanic residual soil and its implications for large landslide phenomena: application to Tenerife, Canary Islands, Eng. Geol., 59, 115-132, 2001.

Hyodo, M., Yoshimoto, N., Nakata, Y., and Kim, W.: Effect of angularity and crushability of particles on shear behaviour of a volcanic soil, in: Powders and Grains, edited by: Garcia-Rojo, R., Hermann, H. J., and McNamara, S., Taylor and Francis, London, UK, 1419-1423, 2005.

Iwamatsu, A., Fukushige, Y., and Koriyama, S.: Applied geology of so-called "Shirasu", non-welded ignimbrite, Journal of Geography, 98, 379-400, 1989 (in Japanese with English abstract).

Jitousono, T., Shimokawa, E., and Teramoto, Y.: A hydrogeomorphological study on landslide of talus slope in valley scarred on Shirasu (pyroclastic flow deposits) plateau in Southern Kyusu, Japan, Transactions, Japanese Geomorphological Union, 23, 611-626, 2002 (in Japanese).

Keefer, D. K. and Johnson, A.: Earth flows: morphology, mobilization, and movement, Geol. Surv. Prof. Paper 1264, U.S. Government Printing Office, Washington D.C., 1983.

Kitamura, R., Miyamoto, Y., and Sako, K.: In situ measurement of suction change in soil due to rainfall in Kagoshima, Japan, in: Geotechnical Engineering, edited by: Ho, K. K. S. and Li, K. S., Swets and Zeitlinger, Lisse, the Netherlands, 291-294, 2003.

Kubota, T. and Omura, H.: Traveling distance of landslides in 2005's Kyushu disaster associated with its application to the land use restriction, in: Disaster Mitigation of Debris Flows, Slope Failures and Landslides, Universal Academy Press Inc., Tokyo, 743-748, 2006.

Lavigne, F. and Thouret, J. C.: Sediment transportation and deposition by rain-triggered lahars at Marapi Volcano, central Java, Indonesia, Geomorphology, 49, 45-69, 2003.

Miyagi, T.: Statistical analysis of dissecting valley in hilly land, Science Reports of Tohoku University, Faculty of Science, Japan, Series 7 (Geography) 163-181, 1977.

Nakano, M., Amemiya, Y., Muto, I., Shiozawa, S., and Nakamura, T.: Physical and hydrologic properties of a Shirasu hill soil properties and water movement in a volcanic deposit (Shirasu) area (II), Transactions of the Japanese Society of Irrigation Drainage \& Reclamation Engineering, 93, 7-12, 1981 (in Japanese).

Nakaoka, S.: The late Quaternary tephra layers from the caldera volcanoes in and around Kagoshima Bay, southern Kyushu, Japan, Geographical reports of Tokyo Metropolitan University, Japan, 23, 47-122, 1988.

Navarro, S., Pulgarín, B., Monsalve, M. L., Cortés, G. P., Calvache, M. L., Pardo, N., and Murcia, H.: Doña Juana Volcanic Complex (DJVC), Nariño: geology and eruptive history, Boletín de Geologia, 31, 109-118, 2009 (in Spanish).

Ngecu, W. M., Nyamai, C. M., and Erima, G.: The extent and significance of mass-movement in Eastern Africa: case studies of some major landslides in Uganda and Kenya, Environ. Geol., 46, 1123-1133, 2004. 
Palacios, D., Zamorano, J., and Gómez, A.: The impact of present lahars on the geomorphologic evolution of proglacial gorges: Popocatepetl, Mexico, Geomorphology, 37, 15-42, 2001.

Palmer, L.: Large landslides of the Columbia River Gorge, Oregon and Washington, in Reviews in Engineering Geology, Landslides, 3, 69-83, 1977.

Sako, K., Yamada, M., and Kitamura, R.: A new slope stability analysis for Shirasu slope, J. Appl. Mech., 3, 497-503, 2000 (in Japanese).

Shimokawa, E., Jitousono, T., and Takano, S.: Periodicity of shallow landslide on Shirasu (Ito pyroclastic flow deposits) steep slopes and prediction of potential landslide sites, Transactions, Japanese Geomorphological Union, 10, 267-284, 1989 (in Japanese).

Sidle, R. C. and Ochiai, H.: Landslides: Processes, Prediction, and Land Use. AGU, Washington, D.C., Water Resources Monograph No. 18, 312 pp., 2006.

Sidle, R. C. and Swanston, D. N.: Analysis of a small debris slide in coastal Alaska, Can. Geotech. J., 19, 167-174, 1982.

Sidle, R. C., Tsuboyama, Y., Noguchi, S., Hosoda, I., Fujieda, M., and Shimizu, T.: Stormflow generation in steep forested headwaters: a linked hydrogeomorphic paradigm, Hydrol. Process., 14, 369-385, 2000.

Sidle, R. C., Taylor, D., Lu, X. X., Adger, W. N., Lowe, D. J., de Lange, W. P., Newnham, R. M., and Dodson, J. R.: Interactions of natural hazards and society in Austral-Asia: evidence in past and recent records, Quartern. Int., 118-119, 181-203, 2004.

Simoni, A., Berti, M., Generali, M., Elmi, C., and Ghirott, M.: Preliminary result from pore pressure monitoring on an unstable clay slope, Eng. Geol., 73, 117-128, 2004.

Sugio, S. and Okabayashi, T.: Unsaturated permeability of Shirasu and its in-situ measuring methods, J. Japan Soc. Civ. Eng., No. 503 (Div. II), 93, 39-47, 1994 (in Japanese).

Suwa, H. and Yamakoshi, T.: Sediment discharge by storm runoff at volcanic torrents affected by eruption, Z. Geomorphol. NF, 114, 63-88, 1999.
Swanson, F. J. and Swanston, D. N.: Complex mass movement terrains in the western Cascade Range, Oregon, Reviews in Engineering Geology, Landslides, 3, 113-124, 1977.

Taniguchi, Y.: Sediment disasters caused by typhoon no. 14, 2005, in Miyazaki Prefecture, International Journal of Erosion Control Engineering, 1, 11-19, 2008.

Takagi, M.: Evapotranspiration and deep percolation of a small catchment with a mature Japanese cypress plantation. J. For. Res.-Jpn., 18, 73-81, 2013.

Takewaka, K.: Characteristics of Shirasu concrete: based on contents in the manual established by Kagoshima Prefecture office, Concrete Journal, 45, 16-23, 2007 (in Japanese).

Teramoto, Y., Shimokawa, E., and Jitousono, T.: Distribution and features of slope failures in Tarumizu City, Kagoshima Prefecture caused by typhoon Nabi in September 2005, Research Bulletin of the Kagoshima University Forests, Kagoshima University, Japan, 34, 1-9, 2006.

Terlien, M. T. J.: Hydrological landslide triggering in ash-covered slopes of Manizales (Colombia), Geomorphology, 20, 165-175, 1997.

Umehara, Y., Zen, K., and Hamada, K.: Engineering properties of Shirasu for construction materials (Part-5) dynamic properties based on dynamic triaxial tests. Tech. Note No. 211, Port and Harbour Inst., Ministry of Transport, Kanagawa, Japan, 79-101, 1975.

Yokota, S.: Deteriorating process of dacitic pyroclastic flow deposits at steep slopes based on hardness distribution, Memoirs of the Graduate School of Science and Engineering, Shimane University, Japan, Series, 30, 27-38, 1997 (in Japanese).

Yokota, S. and Iwamatsu, A.: Weathering distribution in a steep slope of soft pyroclastic rocks as an indicator of slope instability, Eng. Geol., 55, 57-68, 1999.

Yokoyama, S.: Geomorphology of the Ito pyroclastic flow deposit to the north of the Aira caldera, Geographical Review of Japan, 43, 462-482, 1970.

Yokoyama, S.: Rapid formation of river terraces in non-welded ignimbrite along the Hishida River, Kyushu, Japan, Geomorphology, 30, 291-304, 1999. 